\title{
Assamese Travel Literature: An Introductory Note
}

\author{
Chandan Jyoti Chutia
}

Junior Research Fellow, Department of Assamese, Dibrugarh University, Assam, India

\begin{abstract}
How to cite this paper: Chandan Jyoti Chutia "Assamese Travel Literature: An Introductory Note" Published in International Journal of Trend in Scientific Research and Development (ijtsrd), ISSN: 24566470, Volume-3 | Issue-4, June 2019, pp.323-324, URL: https://www.ijtsrd.c om/papers/ijtsrd23 726.pdf

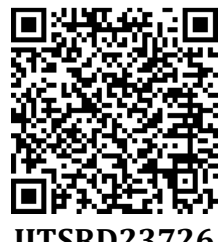

Copyright (C) 2019 by author(s) and International Journal of Trend in Scientific Research and Development Journal. This is an Open Access article distributed under the terms of the Creative Commons

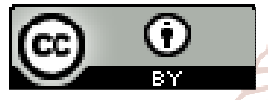
Attribution License (CC BY 4.0) (http://creativecommons.org/licenses/ by $/ 4.0$ )

So, a reader can travel around within his mind through the help of a travelogue. In a travelogue, socio-economic, political and cultural sides of places is also found. Sometimes, a travelogue can be treated as a writ of a place. Minute Observation, fine use of language and lively narrative makes a travelogue very attractive. Assamese travel literature has its own history. In the post independence era, Assamese travel literature was in its grass root stage only and now it has been gradually developing to its best. An attempt is made to establish an introductory description about Assamese travel literature. In other words, here it will be tried to find out the manner of Assamese travel literature.

\section{Travel Literature: An Introductory Note}

Since the birth of human civilization, traveling has always been a human desire. In ancient times, men used to travel for searching food. With the development of human civilization people acquired the ability to record and preserve their experiences in written form. And now travelogue literature is developing like other genres of literature.

People do not travel only for satisfying their curiosity. Traveling makes an individual more richer with new experiences. It also helps people to understand the sociocultural structure of places. So, it must be said that a travelogue is a merge of information's, experiences and the mental satisfaction of a traveler.

According to Hemanta Kumar Bharali, "Traveling countries is not possible for all. People who wish to travel can enjoy travelogues. But there is a fact that the writer should be successful in fulfilling the taste of readers. So that, travelogue literature should give the readers not only the information's, but also the taste of good literature." (Asomkosh, p. 343)

Travelogue can be said as realistic experience centred and descriptive. Equally, it expresses the self-definition and observation of the author. Travel literature helps the readers to achieve knowledge without going to travel. According to Ranjan Bhattacharya, " The experience will get its homour of a literature when it is established as an art expressing the data and information in an artistic way." (Borah, Manjula (Ed.): Bhasha Sahitya Barnali, p. 100-101)

III. Development of Assamese Travel literature :

To name an ancient Travel story, we can take Ram Mishra's 'brindaban Charit'. It was published in the reign of king Jaydhwajj Singha (1645-63). Another important travelogue is 'Tripura Buranji' written in 1724. (Jayanta kumar Borah, Sahityar Nana dix, p. 176)

In real sense, Assamese Travel literature starts its first phase of development in $19^{\text {th }}$ century, Among all the pioneers of Assamese Travel literature, Gunabhiram Boruah was the first we started with his writing of 'Saumar Bhraman'. After travelling to Saumarpeeth, Gunabhiram Boruah wrote this travelogue. So, it is an inter-country travelogue. Ananda Chandra Agarwal, a renowned educationist wrote a travelogue named 'Brahmajatrir Diary' about his Burma travel in the year of 1839 .

In the post independence era, Assamese Travel literature got a rapid development. Because as time flies, changes come to people's lives and professions. People started going abroad 
for higher studies and other reasons also. Post-independence travelogue literature can be divided into two parts as Intercountry travelogue and outer country travelogue. (Jugendra Narayan Bhuyan, chief editor, Biswa kosh $3^{\text {rd }}$ series, p. 705) But in the post-independence era, only outer-country related travelogue is high in amount. In inter-country related travelogue, it includes - Subrata Boruah's 'Himtirtha Bodrinath', Premlata Dutta's 'Alakanandar para Sagar Tiroloy' (from Alakananda to Seabeach), Srinath Devgoswami's 'Panchadham Panchatirtha', Harinarayan Dutta Boruah's 'Bharat Bhraman' (Traveling around India), Anu Boruah's 'Delhir Dukhariya chabi' (Broken images of Delhi), Dipika Bhattacharya's 'Prayagor Pare Pare' (On the bank of Prayag), etc. North-East travel related travelogue includes- Lakheswar Sarmah's 'Misimi Paharar Ronsinga (War bell of Misimi Hills), Premlata Borah's 'Seujia Paharar Maje Maje' (Amidst the green Hills) and Lila Gogoi's 'Simantar Mati aru Manuh' (Men and land of the Border) ect.

Hem Boruah, a well respected poet, critic and Educationist became quite popular though his travelogue 'Sagar Dekhisa' (Have you Seen the Sea), 'Ranga Karabir Ful' (The red Flower Karabi), 'Israel' and 'Mekong noi dekhilu' (I have seen the river Mekong). These travelogues are the result of his tour to many countries at different times. His 'Sagar Dekhisa' is regarded as the first Assamese travelogue written about travelling through America. Some other travelogues related to America are - Birinci Kumar Boruah's Professor Boruahr chithi' (Professor Boruah's Letter), Lakhinandan Borah's 'Seemar paridhi Vangi' (Breaking the circumference of a boundary), Nagen Saikia's 'Americat Dah Din' (Ten days in America), Mahendranath Borah's 'Smritipatat America' (America in my Rememberence), Rathindranath Goswami's 'Maha samudrar Paar' (Banks of the great Sea), Pradipta Borgohain's 'Linclonor Dexor Atithi' (Guest of Linclon's Country), Karabi Deka Hazarika's 'Neela Sagar aru Sonali dex' (Blue Sea and Golden country), Govinda Prasad Sarmah's 'Deffodil Ful Dekhisa' (Have you seen the Deffodil's) etc. There are many travelogues published which are related To Russia Travel. These are to be mentioned Hem Boruah's (Red Flower Karabi), Sayed Abdul Malik's ' Majat Mathun Himalaya' (Only Himalaya is in between), Surendra Mahan Das's 'Tolostoyr dexat' ( In the country of Tolostoy) etc.

The travelogue related to England tour are as follows Prafulla Dutta Goswami's 'Soon Rupar Nahai E dex'(Not a country of gold and silver), Uma Boruah's 'Sien Noir Dhou' (Waves of Sien), Lalit Boruah's 'Europeor Batot' (On the way of Europe), Nirupama Borgohain's 'Sarag Narakar Majedi', (Going through heaven and hell) etc. Some other travelogue containing the travel experiences of China are Hemanga Biswas's 'China sai Ahilu' (Back from China), and 'Akou chin sai ahilu' (Again came from China), Birendra kumar
Bhattacharya's ' Chinat ki Dekhilu' (What I have seen in China) etc. A small number of travelogues expressing the experiences of Japan tour also got published. Among these, Nirmal Prabha Bordoloi's 'Cherry fular dex Japan' ( In the country of Cherry Flower), Mahendra Borah's 'Surjya Utha dex' (Country where Sun rises) and Jayanti Chutia's 'Haiku aru Samurair dexat' (In the country of Haiku and Samurai) etc. are to be mentioned.

Apart from these travelogues, some other travel experiences written by the travelers have contributed to the field of Assamese literature. Some of them to be mentioned such as Gautam Prasad Boruah's 'Dexe Dexe nana rang' (Many colors in many countries), Manuj kumar Goswami's 'Volta Akhan Nadir Nam' (Volta is a name of River), Dhrubajyoti Borah's 'China admiral Jaal', Sunil kumar Saikia's ' Pyramidar dexat' ( In the Country of Pyramid), Saumyadeep Dutta's 'Aranyar sa-puhar' (Shadow and light of a Forest), Jyotishman das's '47 days in SUWAI world' etc.

It is impossible to travel all over the globe for anyone. So, through the help of travelogues we can enjoy the taste of travelling.

\section{Conclusion:}

In the present scenario, it is seen that Assamese Travel literature has achieved a tremendous development. Globalisation and the facilities of tourism is opening many doors for travel. We must say that all the travelogues do not fulfill the literary norms. But, through the help of these travel literature, readers can get an opportunity to understand the socio-cultural status and thoughts of different countries. It can be said that travel literature has made a known identity amongst all the genres of literature. Individualistic, translated, children friendly travelogues is helping in the speedy development of prose literature. Finally it can be said that travel literature has became an integral part of popular contemporary literature.

\section{Reference:}

[1] Bharali, Hemanta Kumar: Asomkosh, Dibrugarh, Banalata, 2007

[2] Bogohain, Homen (Ed.): Asamiya Sahityar Buranji ( $6^{\text {th }}$ Series), Guwahati, Anandaram Baruah Bhasha-KalaSanskriti Sangstha, 1993

[3] Borah, Jayanta Kumar : Sahityar Nana Dish, Dibrugarh, 2010

[4] Borah, Manjula (Ed.) : Bhasha Sahityar Barnali, Jorhat, 2007

[5] Goswami, Jatindranath: Asomiya Sahityar Chamu Buranji, Guwahati, Asom Book, 2002 